\title{
Leptodactylus natalensis (Lutz, 1930) (Amphibia, Anura, Leptodactylidae): First record from Maranhão state and new geographic distribution map
}

\author{
João Manoel A. Leite Jr. ${ }^{1}$ \\ Johnny M. S. Sampaio ${ }^{1,3}$ \\ Roberta Rocha Silva-Leite ${ }^{1,4}$ \\ José Roberto S. A. Leite ${ }^{1,2}$ * \\ ${ }^{1}$ Projeto Biodiversidade do Delta/Conservação e Pesquisa - PROBID \\ Universidade Federal do Piauí - UFPI, Campus Ministro Reis Velloso \\ CEP 64202-020, Parnaíba - PI, Brazil \\ ${ }^{2}$ Instituto Ilha do Caju Ecodesenvolvimento e Pesquisa - ICEP \\ ${ }^{3}$ Universidade Estadual do Piauí - UESPI \\ ${ }^{4}$ Programa de Pós-graduação em Desenvolvimento e Meio Ambiente \\ Núcleo de Referência em Ciências Ambientais do Trópico Ecotonal do Nordeste (TROPEN) \\ Universidade Federal do Piauí - UFPI \\ *Corresponding Author \\ jrleite@ufpi.br
}

Submetido em 18/01/2008

Aceito para publicação em 28/04/2008

\section{Abstract}

The presently known distribution of Leptodactylus natalensis is no longer restricted to the northern and central limits of the Atlantic forest morphoclimatic domain. After Borges-Nojosa encountered it in the Caatinga at the time of this work, during a field expedition in the Parnaíba Delta in December 2007, we identified and collected some individuals of L. natalensis on the Ilha das Canárias, Araioses, located in northern Maranhão state. This new record for Maranhão extends the distribution of L. natalensis to approximately $520 \mathrm{~km}$ west of the Serra de Baturité, in the state of Ceará.

Key words: Leptodactylus natalensis, Parnaíba Delta, geographic distribution

\section{Resumo}

Leptodactylus natalensis (Lutz, 1930) (Anfíbios, Anuros, Leptodactylídeos): Primeiro registro para o Estado do Maranhão e novo mapa de distribuição geográfica. O presente conhecimento sobre a distribuição de Leptodactylus natalensis, não se restringe mais aos limites norte e central do domínio morfoclimático floresta atlântica. Após Borges-Nojosa encontrá-lo na caatinga, a equipe deste trabalho durante uma expedição de campo no Delta do Parnaíba, em dezembro de 2007, identificou e coletou alguns indivíduos de L. natalensis na Ilha das Canárias, município de Araioses, norte do estado do Maranhão. Esse novo registro para o Maranhão estende a distribuição de L. natalensis aproximadamente $520 \mathrm{~km}$ a oeste da Serra de Baturité, estado do Ceará e configura o primeiro registro para uma ilha costeira.

Unitermos: Leptodactylus natalensis, Delta do Parnaíba, ampliação de distribuição geográfica. 
The Leptodactylus genus is divided into five groups: ocellatus, fuscus, melanonotus, pentadactylus and marmoratus (Heyer, 1969), the last of which is still undergoing acceptance by various authors. Leptodactylus natalensis is a member of the L. podicipinus-wagneri complex of the L. melanonotus group (sensu Heyer, 1994). Lutz (1930) described the species in Rio Baldo, Natal, in the state of Rio Grande do Norte, northeast Brazil. The knowledge about the distribution of this species was associated for a long time with the northern and central portions of the Atlantic forest morphoclimatic domain (Ab'Sáber, 1977) from its most northern extent in the State of Rio Grande do Norte to the state of Rio de Janeiro (Heyer and Heyer, 2006). In a recent survey of the herpetofauna of the Serra de Baturité, in Ceará state, Borges-Nojosa (2007) registered this species at this location and broadened its known distribution to the east side of the state. Despite this, it was never described as living on coastal islands. During field work in the Parnaíba Delta in December 2007, we found and collected some individuals of $L$. natalensis (Figure 1) on the Ilha das Canárias (S02 ${ }^{\circ} 47^{\prime} 48.9^{\prime \prime}$ and W041'52'12.1"), Araioses, northern Maranhão state (Figures 2 and 3).

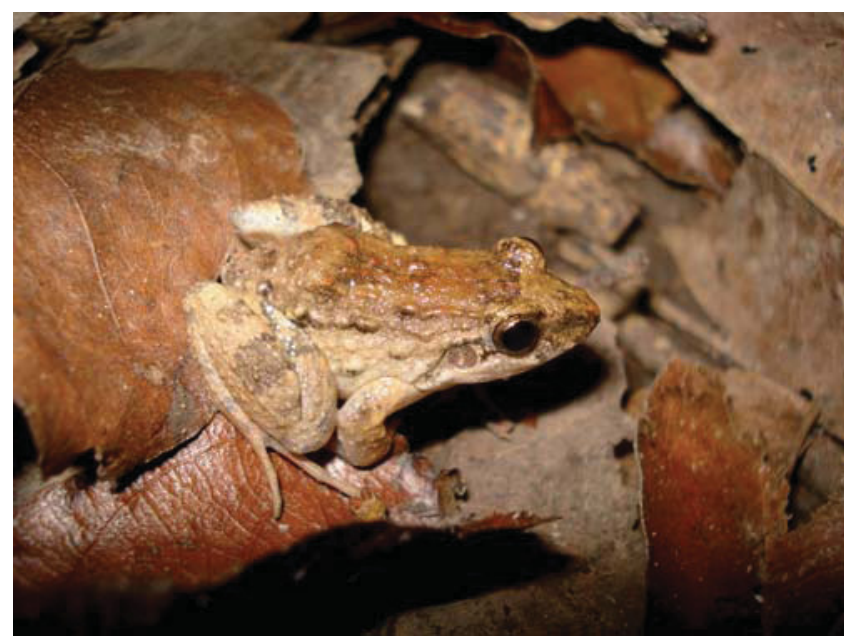

FIGURE 1: Adult male of Leptodactylus natalensis Lutz, 1930 (CHDP 0022) in temporary ponds on the Ilha das Canárias (Delta do Parnaíba), Maranhão, Brazil. Collected in December 2007 (Photo: João Manoel de Almeida Leite Júnior).

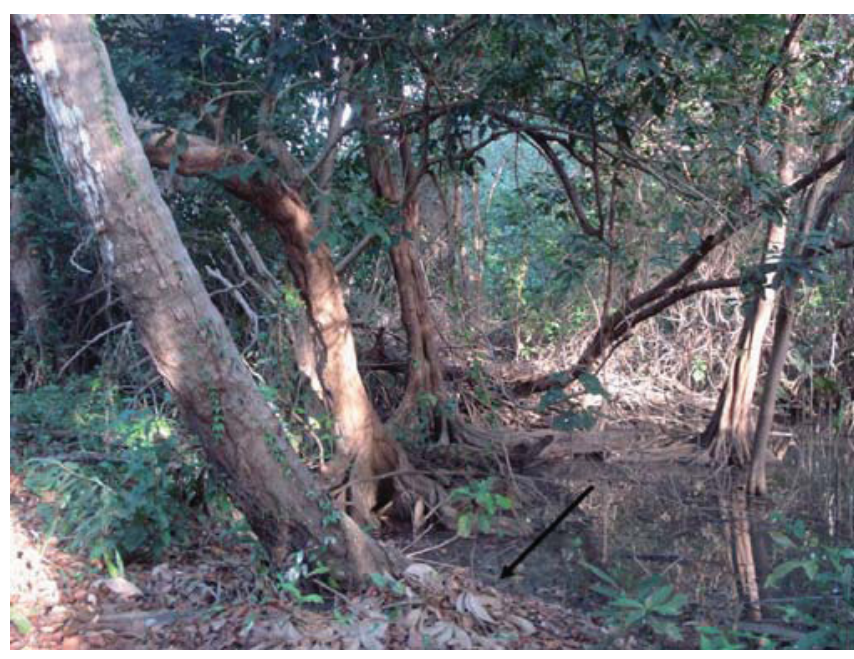

FIGURE 2: Study area on Ilha das Canárias (Photo: João Manoel de Almeida Leite Júnior).

The Parnaíba Delta matches a region of estuary characterized mainly by mangroves. At its mouth, the Parnaíba River forms a complex of approximately 70 islands. This complex is formed by five large islands distributed between two states: Piauí and Maranhão. The second largest island is Ilha das Canárias, belonging to the state of Maranhão (Figure 3B). This new record for Maranhão extends the distribution of $L$. natalensis to approximately $520 \mathrm{~km}$ west of the Serra de Baturité, being the closest place this species was found.

The collected specimens, fixed in $10 \%$ formalin and preserved in $70 \%$ ethanol, were identified based on the original description and deposited in the Coleção Herpetológica Delta do Parnaíba (CHDP) under numbers CDHP 0022-0025. Some physical parameters, along with data collected as the characteristics of the individuals, were subsequently analyzed and compared with individuals in other locations. The minimum and maximum temperatures and moisture registered at this spot were $27.1^{\circ} \mathrm{C} / 63 \%$ and $30.9^{\circ} \mathrm{C} / 73 \%$ respectively, between 5:00pm and 5:00am, with water temperature around $27.7^{\circ} \mathrm{C}$. Measurements $(\mathrm{SVL}=$ snouth vent length) were taken with a digital caliper to the nearest $0.01 \mathrm{~mm}$, but then, to avoid pseudo precision, we rounded all measurements to just one decimal. The results were $7 \mathrm{~g}$ for the average weight and $39.15 \mathrm{~mm}$ for the SVL $(n=8)$. 


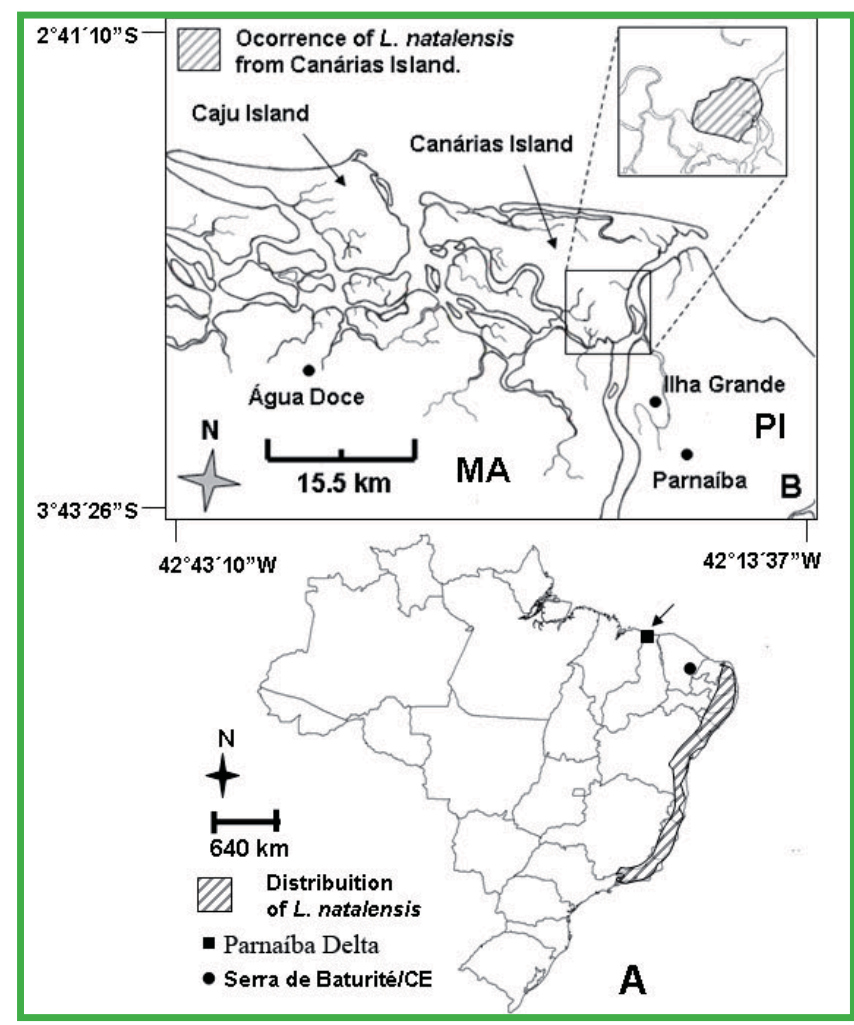

FIGURE 3: (A) Distribution and new occurrence map of $L$. natalensis. (B) Insert for Parnaíba Delta region.

The most remarkable fact is that this species is found in a completely different biome to that previously described, as already shown by Borges-Nojosa (2007), because although the coasts of Piauí and Maranhão are currently classified as Atlantic Forest according to federal law number $11,428 / 2006$, this region has a climate and vegetation that are very different from the Atlantic Forest that belongs to the region previously described for this species, thus corresponding to a region of transition between the Atlantic Forest and the Amazon region (see Figure 2).

Males of L. Natalensis can be found within pits dug by them in the soil, between exposed plant roots, near the water's edge and under fallen leaves (Amorim et al., 2007). On Canárias Island, the individuals of L. natalensis were on the banks of an igarapé (term used in the region for primary or secondary springs of rivers) jumping on the foliage at dusk, using mainly the higher roots of trees to hide. In this region, the igarapés usually suffer much influence of the tide, increasing the salinity of the water. The water level oscillations in this place may exceed $3 \mathrm{~m}$. While no tests of the water's salinity were carried out, we believe that this process makes the environment somewhat unsuitable for the breeding of amphibians. However, this population of L. natalensis seemed well adapted to the environment, because we noticed some specimens that were partially submerged.

Analyzing the proposed new map for the distribution of the species, we can recognize that its occurrence now extends along the coast of the northeast region, and this reflects that, in this corridor, there is a huge shortage of studies in the area of herpetology.

These new records are important for a reassessment of the conservation status of this species. Our report is another typical example of how poorly known the distribution and abundance of Brazilian anurans is (Marques et al., 2006). Knowledge of the biological diversity of the Parnaíba Delta will bring information required in the future development of public policies for the conservation of this region.

\section{Acknowledgements}

The authors thank in particular the guide of the expedition, Mister Pedro da Costa e Silva, for his deep knowledge in the deltaic region, and Etielle Barroso de Andrade for scientific illustration of the Parnaíba Delta. This work was partially financed by grants from the Universidade Federal do Piauí (Piauí, Brazil) and the Programa Petrobrás Ambiental. Instituto Chico Mendes APA Delta (Instituto Brasileiro do Meio Ambiente e dos Recursos Naturais Renováveis) kindly provided the collection permit. The authors are grateful to ICEP (Instituto Ilha do Caju Ecodesenvolvimento e Pesquisa) and IBAMA (Escritório Regional de Parnaíba) for logistic support. Language review was carried out by Claudia Hissette.

\section{References}

Ab'Sáber, A. N. 1977. Os domínios morfoclimáticos na América do Sul. Primeira aproximação. Geomorfologia, 52: 1-23 + 1 map.

Amorim, F. O.; Peixoto, K. E. V. S.; Santos, L. C. S.; Santos, E. M. 2007. Temporada e turno de vocalização de Leptodactylus natalensis Lutz, 1930 (Amphibia), em mata atlântica de Pernambuco. 
Anais do III Congresso Brasileiro de Herpetologia, Belém, Brazil, CD-ROM.

Borges-Nojosa, D. M. 2007. Diversidade de anfíbios e répteis da serra de Baturité, Ceará. In: Oliveira, T. S. \& Araújo, F. S. (eds). Diversidade e conservação da biota na serra de Baturité, Ceará. UFC, Coelce, Fortaleza, Brazil, p.225-247.

Downie, J. R. 1996. A new example of female parental behaviour in Leptodactylus validus, a frog of the leptodactylid "melanonotus" species group. Herpetological Journal, 6: 32-34.

Heyer, R. 1969. The adaptive ecology of the species groups of the genus Leptodactylus (Amphibia, Leptodactylidae). Evolution, 23: 421-428.

Heyer, R. 1994. Variation within the Leptodactylus podicipinuswagneri complex of frog (Amphibia, Leptodactylidae). Smithsonian Contributions to Zoology, 546: 1-124.

Heyer, W. R.; Heyer, M. M. 2006. Leptodactylus natalensis A. Lutz bubbling frog. Catalogue of American Amphibians and Reptiles, 808: $1-5$.

Lutz, A. 1930. Segunda memória sobre espécies brasileiras do gênero Leptodactylus, incluindo outras aliadas. Second paper on Bra- zilian and some closely related species of the genus Leptodactylus. Memórias do Instituto Oswaldo Cruz, 23: 1-20 (Portuguese), 21 34 (English) + plates 1-5.

Marques, R. M.; Colas-Rosas, P. F.; Toledo, L. T.; Haddad, C. F. B. 2006. Amphibia, Anura, Bufonidae, Melanophryniscus moreirae: distribution extension. Check List, 2 (1): 68-69.

Martins, I. A. 2001. Parental care behaviour in Leptodactyulus podicipinus (Cope, 1982) (Anura, Leptodactylidae). Herpetological Journal, 11: 29-32.

Prado, C. P. A.; Uetanabaro, M.; Haddad, C. F. B. 2002. Description of a new reproductive mode in Leptodactylus (Anura, Leptodactylidae), with a review of the reproductive specialization toward terrestriality in the genus. Copeia, 4: 1128-1133.

Santos, E. M.; Amorim, F. O. 2006. Cuidado parental em Leptodactylus natalensis (Amphibia, Anura, Leptodactylidae). Iheringia, Série Zoologia, 96 (4): 491-494.

Wells, K. D.; Bard, K. M. 1988. Parental behavior of an aquaticbreeding tropical frog, Leptodactylus bolivianus. Journal of Herpetology, 22: 361-364. 